\title{
Effect of the 2008 chaitén volcano eruption over the antarctic snowfall
}

\author{
Efecto de la erupción del volcán Chaitén 2008 \\ en la precipitación nivosa de la antártica
}

P. Cid-Agüero ${ }^{1}$, C. Toro ${ }^{2}$, R. Khondoker ${ }^{3}$, M. Salamanca ${ }^{4}$, B. Jara ${ }^{3}$ \& C. Cárdenas ${ }^{2}$

\section{Resumen}

Se ha llevado a cabo una investigación del impacto potencial sobre la Antártica de la erupción del volcán Chaitén, ubicado en el sur de Chile (4249'58'S - 72³8'45”O). Variaciones en el contenido de elementos químicos principales en la precipitación nivosa fresca en la base antártica chilena B. O'Higgins fue monitoreado por ICPMS análisis durante el año 2008. Sus principales componentes y las proporciones isotópicas de plomo se compararon con la composición química de las cenizas recolectadas durante la erupción. Los resultados del análisis indican un cambio significativo en la composición de la nieve antártica a partir de agosto de 2008, cuatro meses después de la erupción del volcán. Se encontró un aumento en el pH y la concentración de varios elementos en la nieve. Además, se detectó un fuerte enriquecimiento del contenido de azufre en las nevadas antárticas.

\section{Palabras clave:}

Antártica, precipitación nivosa, ceniza volcánica, Chaitén

\footnotetext{
Abstract

An investigation of the potential impact on the Antarctic by the 2008 eruption of Chaiten volcano, located in southern Chile (42\%49'58'S $\left.-72^{\circ} 38^{\prime} 45^{\prime \prime} \mathrm{W}\right)$, has been conducted. Major elements content in fresh snowfall was monitored by ICP-MS analysis during the years 2008, at the B. O`Higgins Antarctic Chilean base. Its major chemical components and lead isotopic ratios were
}

compared with the chemical composition of ashfall collected during the eruption. Results from the chemical analysis indicate a significant change in the Antarctic snowfall composition starting in August 2008, four months after the volcano eruption. An increase in the $\mathrm{pH}$ and the concentration of several elements in the snowfall was found. Additionally, a strong enrichment of sulfur content in the Antarctic snowfall was detected.

\section{Key words:}

Antarctic, snow precipitation, volcanic ashes, Chaitén.

\section{INTRODUCTION}

Several studies showed that the impact of explosive volcanic eruptions reaches far beyond the immediate surrounding areas (Robock et al. 2000; Millard et al. 2006; Martin et al. 2009; Delfosse et al. 2005; Gauci et al. 2008). The global chemical impact of these eruptions may be seen as fine

1 Dirección de Programas Antárticos, Universidad de Magallanes, casilla 113-D, Chile. $\bowtie$ pedro.cid@umag.cl

2 Facultad de Ciencias, Universidad de Magallanes, casilla 113-D, Chile

3 Department of Earth Sciences, Imperial College, London, SW7 2AZ, United Kingdom

4 Departamento de Oceanografía, Universidad de Concepción, casilla 2407, Chile 
volcanic ashes, aerosols and gases dispersed widely through the atmosphere. The changing wind patterns together with seasonality in circulations leads to varied depositions in the polar snow. This deposition may be used to fingerprint geological events such as volcanic eruptions, cyclones and tsunamis. In the same way, high aerosol contents are generally reflected by increased concentrations of particulate matter in the snow. In Antarctica, the main source of information for past volcanic activities proceeds from ice core analysis, showing the strong impact of these events on the concentration of sulfur and other elements in stratospheric aerosols (Zielinski et al. 1997; Zielinski et al. 2000; Gao et al. 2007).

One of the most recent volcanic activities within the southernmost region of the Andes surprised scientists (Carn et al. 2009; Major \& Lara, 2013), as the Chaitén volcano was considered inactive, and the only recorded eruption happened about 9300 years BP (Naranjo et al. 2004). The Chaitén volcano, located in the Chilean Andes, (42 49'58'S-72 $38^{\circ} 45^{\prime}$ 'W), erupted violently on May 2, 2008, reaching its maximum explosive phase on May 6 and continued as a variable but gradually decreasing emission of ash until 2009 (Major \& Lara, 2013). The column of ashes and vapor reached between 11 and 17 kilometers high in the atmosphere (Smithsonian's Global Volcanism Program). According to its characteristics, the Chaitén eruption is classified as Plinian, being comparable in magnitude to the explosive eruptions of Mount Saint Helens in 1980, El Chichón in 1982 and Pinatubo in 1991. This kind of eruption injects large amounts of ashes and vapors into the stratosphere, which are distributed around the globe (Bursik, 2001). These eruptions could be important factors for the climate change (von Glasow et al. 2008; Major \& Lara, 2013), with influences lasting from hours to decades (Robock, 2000; Dorries, 2006; Fischer et al. 2007). For instance, the Pinatubo eruption was strong but relatively short, and produced the largest cloud of sulfur dioxide of the twentieth century. The cloud of combined aerosols from Pinatubo covered the globe during months. The collected data shows that the average temperature of the planet decreased by $0.5^{\circ} \mathrm{C}$ within the two following years (Fischer et al. 2007; Ottera et al. 2008).

From the chemical point of view, each vol- cano and each eruption present a particular fingerprint in the composition of the tephra and the proportion of its components, providing key information for its source identification (Lopez-Escobar et al. 1993; D'Orazio et al. 2003; Laluraj et al. 2009). Explosive eruptions inject large amounts of different kind of particles and gases, such as water vapor, carbon dioxide $\left(\mathrm{CO}_{2}\right)$, sulfur dioxide $\left(\mathrm{SO}_{2}\right)$, chloride $(\mathrm{Cl}-)$, fluoride $(\mathrm{F}-)$, and ashes into the stratosphere. The main part of the ashes is rapidly eliminated from the atmosphere in a period of days or a few weeks; however, the gases and the smallest particles injected could remain for large periods of time. These aerosols reflect the solar radiation, thus cooling the atmosphere, and even can destruct the ozone layer (Sato et al. 1993;Hickey-Vargas et al. 1995; Gutierrez et al. 2005; Lopez-Escobar et al. 1995; Selles et al. 2004; Tilmes et al. 2008).

Antarctica is not the isolate pristine environment as it may seem; it is rather well connected to other continents, either by winds or oceanic currents, therefore it is exposed to natural and anthropogenic pollution sources. It is a well-known fact that the atmospheric circulation provides a constant supplier of dust and contaminants to Antarctica, especially from South America (Gaiero et al. 2007). All these contributions produce substantive chemical composition changes in the Antarctic atmosphere, as a result of photochemical reactions, heterogeneous reaction of gases with aerosols, snow in the atmosphere and snow on the ground (Barrie et al. 1994).

This study reports the results of the chemical characterization of volcanic ashes of the 2008 Chaitén eruption, and snowfall within the Antarctic Peninsula during some months after this eruption. Due to snow being a major player in the chemistry and scavenging of pollutants from the atmosphere, the objective was to determine the occurrence of volcanic material within the Antarctic snowfall and the chronology of the arrival of such pollutants to the White Continent.

\section{METHODOLOGY}

\section{Sample collection}

During this study, between May 11 and 13, 2008, ashes from the Chaitén eruption were col- 


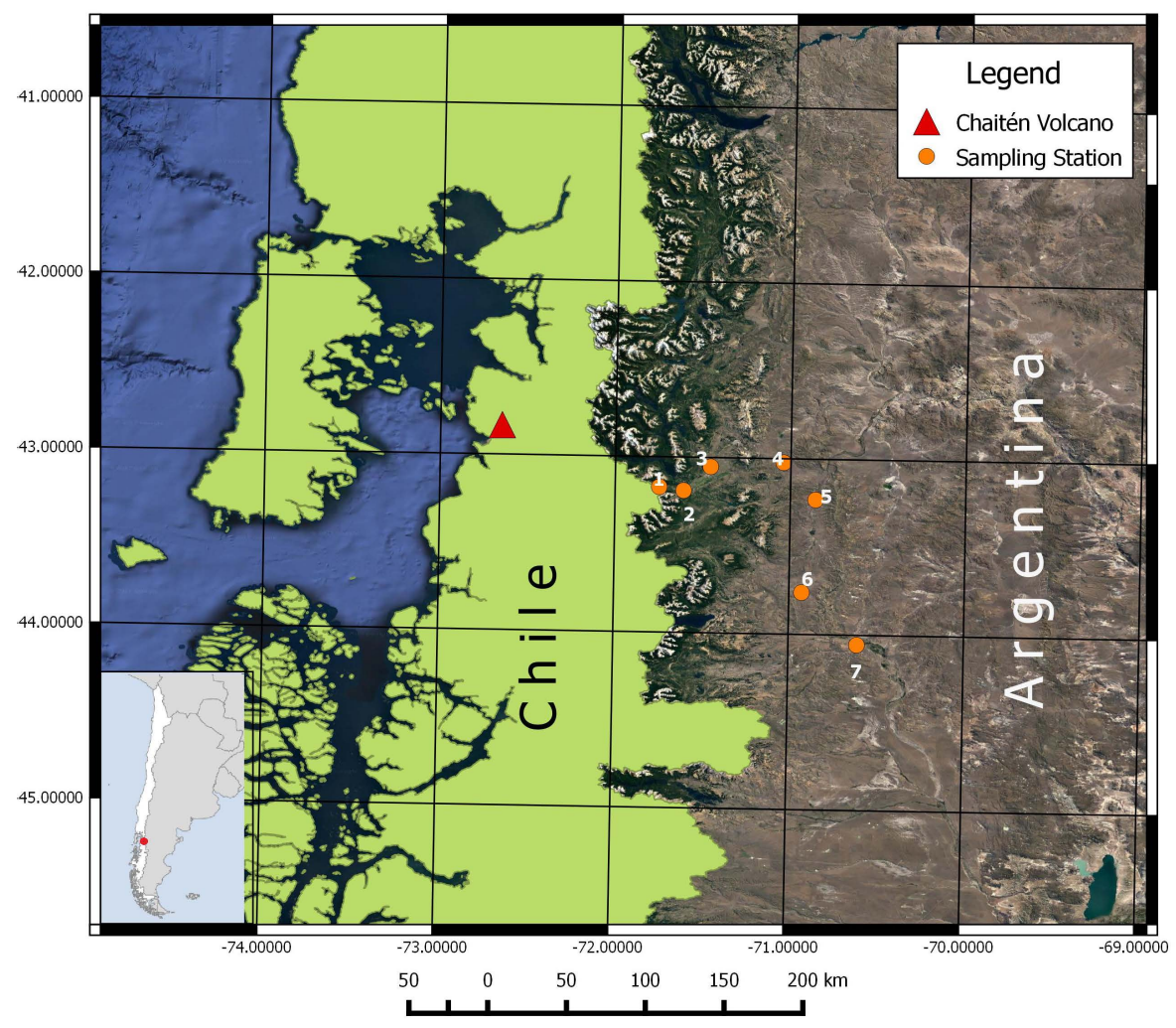

Table indicating the coordinates for the ash sample stations

\begin{tabular}{|crl|}
\hline $\begin{array}{c}\text { Sampling } \\
\text { Station } \\
\text { Number }\end{array}$ & $\begin{array}{r}\text { Latitude } \\
\text { South }\end{array}$ & $\begin{array}{l}\text { Longitude } \\
\text { West }\end{array}$ \\
\hline 1 & $4^{\circ} 10^{\prime} 20^{\prime \prime}$ & $71^{\circ} 44^{\prime} 54^{\prime \prime}$ \\
2 & $4^{\circ} 11^{\prime} 25^{\prime \prime}$ & $71^{\circ} 36^{\prime} 33^{\prime \prime}$ \\
3 & $43^{\circ} 03^{\prime} 10^{\prime \prime}$ & $71^{\circ} 27^{\prime} 24^{\prime \prime}$ \\
4 & $43^{\circ} 01^{\prime} 21^{\prime \prime}$ & $71^{\circ} 02^{\prime} 27^{\prime \prime}$ \\
5 & $4^{\circ} 13^{\prime} 55^{\prime \prime}$ & $70^{\circ} 51^{\prime} 20^{\prime \prime}$ \\
6 & $43^{\circ} 45^{\prime} 40^{\prime \prime}$ & $70^{\circ} 55^{\prime} 40^{\prime \prime}$ \\
7 & $4^{\circ} 03^{\prime} 20^{\prime \prime}$ & $70^{\circ} 36^{\prime} 30^{\prime \prime}$ \\
\hline
\end{tabular}

Projection WGS84

EPSG: 4326

Chaitén Volcano

Palena Province, Los Lagos Region Chile

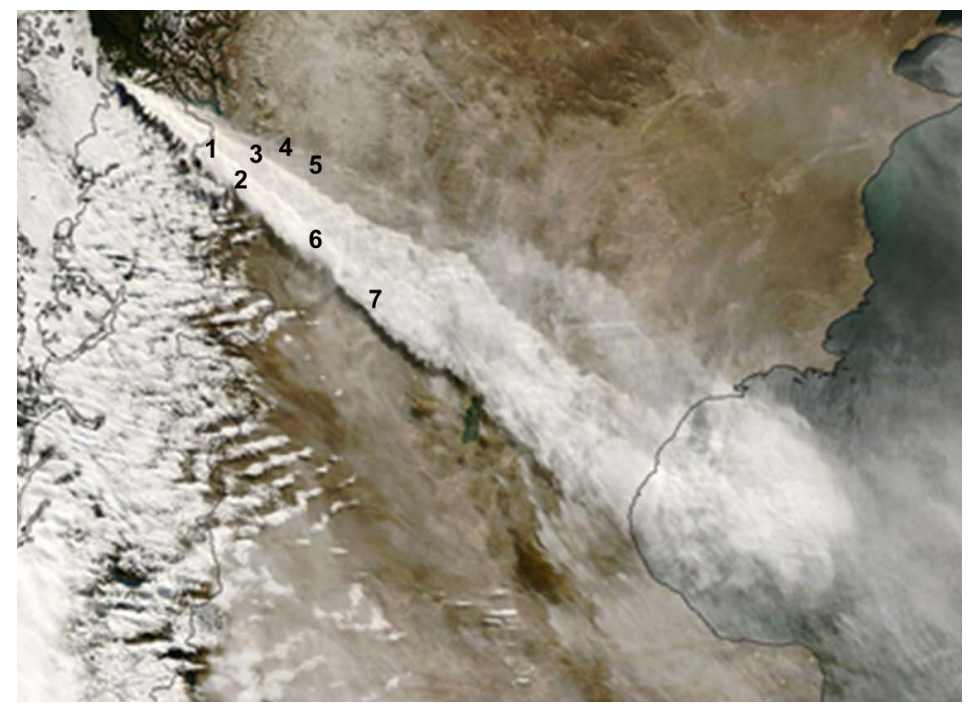

Fig. 1. (A) Map for the ash sample stations including a table with their coordinates. (B) Moderate Resolution Imaging Spectroradiometer (MODIS) image captured from NASA's Terra satellite shows Chaitén eruption plume dispersed across Argentina and the Atlantic Ocean. NASA MODIS Rapid Response Team, 3 May 2008, 14:35 UTC. Numbers within the image show the seven ash collection stations used for the present study. 
lected in 7 stations that were situated within an area of $200 \mathrm{~km}$ from the volcano, following the western direction of the plume (Fig. 1). This methodology allowed the collection of pristine fallout ashes, unaffected by post-deposition processes. Consequently, during the year 2008, monthly samples of snowfall precipitation were collected at the O'Higgins base on the Antarctic Peninsula (6319'49"S - 57॰52'28”W).

Duplicated samples of pristine ash were stored in sealed Nasco, Whirl-Pak sterile polyethylene bags. Samples of Antarctic fresh snow were collected at O'Higgins base in the Antarctic Peninsula immediately after precipitation during the period from May to November 2008. Each snow sample, weighing approximately $1 \mathrm{~kg}$, was carefully collected wearing disposable polyethylene gloves and stored in sealed polyethylene bags, and then kept frozen at $-20^{\circ} \mathrm{C}$, until it was shipped to Punta Arenas for chemical analysis.

\section{Chemical analysis}

The snow was melted by letting the closed sample bags sit in a warm water bath at room temperature. The $\mathrm{pH}$ was measured no later than 3 hours after melting using a desktop pH-meter, HANNA model HI 9321.

For major and trace elements determination in ash, parallel analyses in two independent laboratories were performed, while the snow samples were analyzed only by the first technique. The following is a description of both methodologies:

a)Elemental composition determination by Inductively Coupled Plasm-Mass Spectrometer (ICP-MS)

An ICP-MS was used to determine the elemental chemical composition of both ash and snow samples. Briefly, one hundred milligrams of dry ashes (triplicate) was acid digested with a mixture of concentrated Suprapur ${ }^{\circledR} \mathrm{HCl}$ and Suprapur ${ }^{\circledR}$ bi-distillated nitric acid from Merck $(4 \mathrm{ml} \mathrm{HCl}$ : $1 \mathrm{ml} \mathrm{HNO}_{3}$ ), in a Milestone Ethos D Microwave oven, and then treated with enough HF to further dissolve the silicates. Then, the resulting solution was centrifuged and the supernatant was doubly evaporated to incipient dryness with addition of
$\mathrm{HNO}_{3}$, and finally made up to $100 \mathrm{ml}$ with deionized water and $1 \%(\mathrm{v} / \mathrm{v}) \mathrm{HNO}_{3}$ an aliquot of this solution was injected into a ThermoScientific XSeries 2 quadrupole ICP-MS. The instrument was calibrated with a tune solution covering masses from Lithium to Uranium, and a reactive blank was also read. Major (Sodium, Magnesium, Aluminum, potassium, Calcium, Manganese and Iron) and trace elements (such as Sulfur, Scandium, Vanadium, Chromium, Cobalt, Nickel, Copper, Zinc, Arsenic, Yttrium Cadmium, Lead and Thorium) were measured on the ash and snow samples. The results were expressed in counts per second (cps), normalized for each element.

b) Elemental composition determination by Induced Coupled Plasm- Atomic Emission Spectroscopy (ICP-AES)

Fifty milligrams of ashes were weighed into a screw top PTFE vessels and all total digestion was done by $\mathrm{HF} / \mathrm{HNO}_{3}$ method on a hotplate for $48 \mathrm{hrs}$ at $120{ }^{\circ} \mathrm{C}$ followed by a $6 \mathrm{M} \mathrm{HCl}$ step, then nitric conversion. Samples were the evaporated to dryness and re-fluxed twice in $0.5 \mathrm{ml}$ of $15.6 \mathrm{M}$ nitric acid to dissolve solid fluorides. After digestion, the samples were diluted with ultrapure water to obtain ca. $4 \mathrm{ml}$ of sample solution in ca. $0.8 \mathrm{M} \mathrm{HNO}_{3}$. Then $1.5 \mathrm{ml}$ of this solution was used for elemental concentration analysis and $1.5 \mathrm{ml}$ was taken for $\mathrm{Pb}$ isotope ratio measurements. Major elements (Sodium, Magnesium, Aluminum, potassium, Calcium, Manganese and Iron) and trace elements (Scandium, Vanadium, Chromium, Cobalt, Nickel, Copper, Zinc, Yttrium, Cadmium, Lead and Thorium) concentrations and trace elements abundance were determined by inductively coupled plasma atomic emission spectroscopy using a Thermo iCap 6500 Duo (Khondoker, 2014).

Data quality was monitored by using the certified reference material USGS G-2 granite $(\mathrm{n}=12)$. All $\mathrm{Pb}$ isotope ratio data were corrected for mass bias and $\mathrm{Tl}$ optimization.

\section{Method for lead isotope ratios}

Lead was isolated from the sample matrix by ion exchange chromatography using Eichrom Sr spec resin (Weiss et al. 2004). Neodymium 
was isolated using a two-step column procedure (Pin \& Zalduegui, 1997). The REE fraction was separated from the sample matrix using Eichrom TRU spec resin, followed by isolation of the $\mathrm{Nd}$ fraction from the other REE using Eichrom Ln spec resin on volumetrically calibrated Teflon columns. Lead and neodymium isotopic compositions were analysed on a Nu Plasma (Nu Instruments Limited, UK) multiple collector inductively coupled plasma mass spectrometer (MC-ICP-MS). The samples were introduced with a Nu DSN-100 Desolvation Nebulizer System and PTFE nebulizer.

For $\mathrm{Pb}$ isotope analysis, samples and NISTSRM8 $981 \mathrm{~Pb}$ standards were doped with NISTSRM $997 \mathrm{Tl}$ to yield $\mathrm{Pb} / \mathrm{Tl}$ ratio of $3: 1$. The instrument mass bias was corrected for using the $\mathrm{Tl}$ as an external spike (Weiss et al. 2004). The precision and accuracy of $\mathrm{Pb}$ isotope ratio measurements were assessed using certified reference material USGS G-2 granite. Samples were measured over a five-month period. Repeat measurements yielded ${ }^{206} \mathrm{~Pb} /{ }^{204} \mathrm{~Pb}$ values $=18.399$ $\pm 0.005,{ }^{207} \mathrm{~Pb} /{ }^{204} \mathrm{~Pb}=15.640 \pm 0.006$, and ${ }^{208} \mathrm{~Pb} /{ }^{204} \mathrm{~Pb}=38.902 \pm 0.021(\mathrm{n}=22)$. Reported $\mathrm{Pb}$ isotope results for USGS G-2 granite were in agreement with published data (18.396 \pm 0.023 , $15.636 \pm 0.005,38.900 \pm 0.019$, respectively; Weis et al. 2006).

\section{RESULTS AND DISCUSSION}

\section{Volcanic ashes}

Ash characterization by both analytical methods showed $\mathrm{Na}, \mathrm{Mg}, \mathrm{Al}, \mathrm{K}, \mathrm{Ca}, \mathrm{Mn}$ and $\mathrm{Fe}$ to be the major elements besides $\mathrm{Si}$, while in a lesser extent, Sc, V, Cr, Co, Ni, Cu, Zn, Y, Pb, Cd, and Th were found. Table 1 shows the main components of the Chaitén ashes expressed as oxide in \% $\mathrm{v} / \mathrm{v}$ as well as the concentration of traces expressed in $\mu \mathrm{g} \mathrm{g}^{-1}$.

Several reports have regarded the magmatic material composition from the 2008 Chaitén eruption (Castro et al. 2009; Martin et al. 2009; Ruggieri et al. 2011), showing approximately $72 \%$ $\mathrm{SiO}_{2}, 15 \% \mathrm{Al}_{2} \mathrm{O}_{3}, 4 \% \mathrm{~K}_{2} \mathrm{O}, 2 \%$ de $\mathrm{CaO}$ y $\mathrm{Fe}_{2} \mathrm{O}_{3}$ a phosphorus average content of $10-20$ ppm calcium 1000-2000 ppm, and a magnesium content higher than 180 ppm (Buduba et al. 2008). These outcomes are consistent with our results, which are given by difference an approximated $75.9 \% \mathrm{w} / \mathrm{w}$ abundance of $\mathrm{SiO}_{2}$. Prata et al. (2008) suggest that the rhyolitic Chaiten's volcanic eruption is unusual, generating an acidic and viscous magma that may explain the observed strong explosive eruption.

\section{Antarctic snowfall}

The main constituents in Antarctic snow samples corresponded to sodium, representing in average $89 \%$ of the total composition, magnesium with $5 \%$, and minor constituent such as potassium $(2 \%)$ and iron (1\%). Also the presence of silicon, zinc, sulfur, aluminum and metals at trace levels were detected. In general, the elemental composition agreed with previous finding in glaciers in the Southern Ice Fields (Grigholm et al. 2009). For purposes of comparison, the normalized signal intensities in cps for each isotope were used. When the temporal variation of the main elements in chemical composition of snowfall is analyzed, we can observe that the

Table 1. Main components of volcanic ashes expressed as oxide concentrations in $\% \mathrm{w} / \mathrm{w}$ and trace elements concentrations expressed as $\mu \mathrm{g} g-1$.

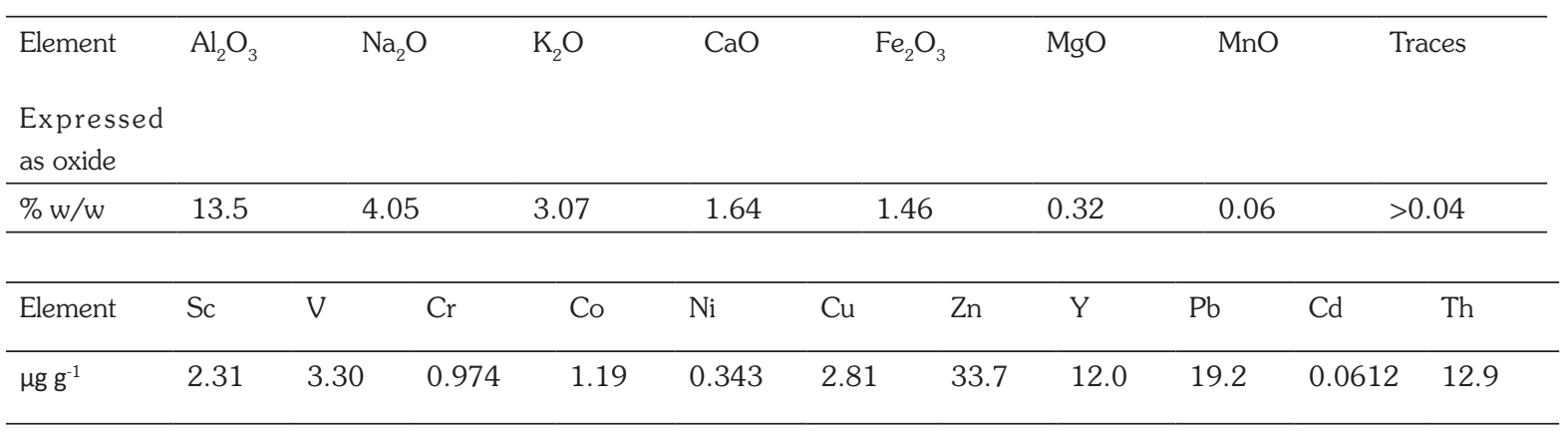


relative abundance of some elements such as $\mathrm{Na}$, $\mathrm{K}, \mathrm{Mg}$ and $\mathrm{S}$ increased drastically in the month of August (Fig. 2A), and some others like $\mathrm{Fe}, \mathrm{Al}$ and $\mathrm{Si}$ reached their maximum increment in the month of September (Fig. 2B). These increments cannot be explained by natural seasonal variations, which have been monitored in previous studies (Weller et al. 2008). Conversely, our unusual results can only be explained if we consider an extra source for these elements, as may be the ashes coming from the Chaitén's eruption. This idea of South America as a source of pollution in the Antarctic continent is not new. Prospero et al. (2002) showed that there are three persistent dust sources from South America: Patagonia $\left(39^{\circ}-52^{\circ} \mathrm{S}\right)$, central-western Argentina $\left(26^{\circ}-33^{\circ} \mathrm{S}\right)$, and the Puna-Altiplano plateau $\left(19^{\circ}-26^{\circ} \mathrm{S}\right)$. They also suggested that these sites were probably much more active during the LGM (Last Glacial Maximum). However, to the best of our knowledge, this is the first time that

a)

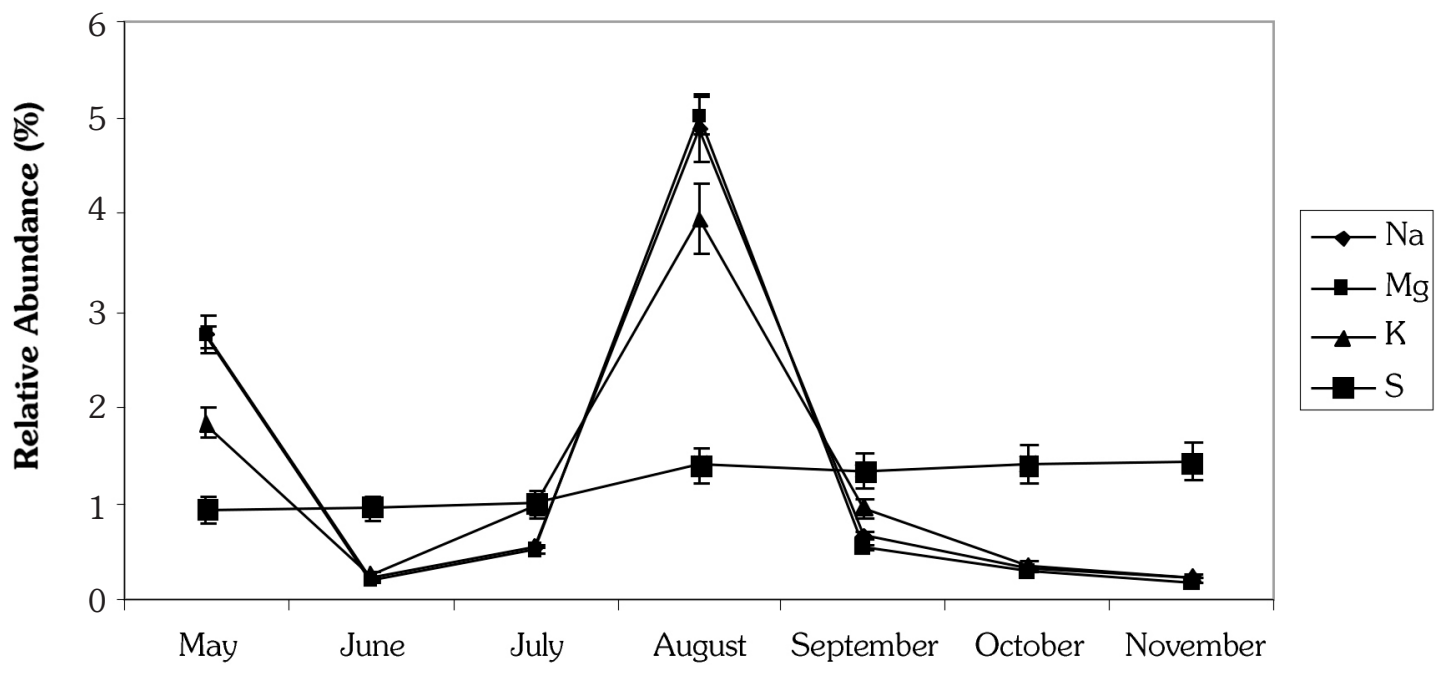

b)

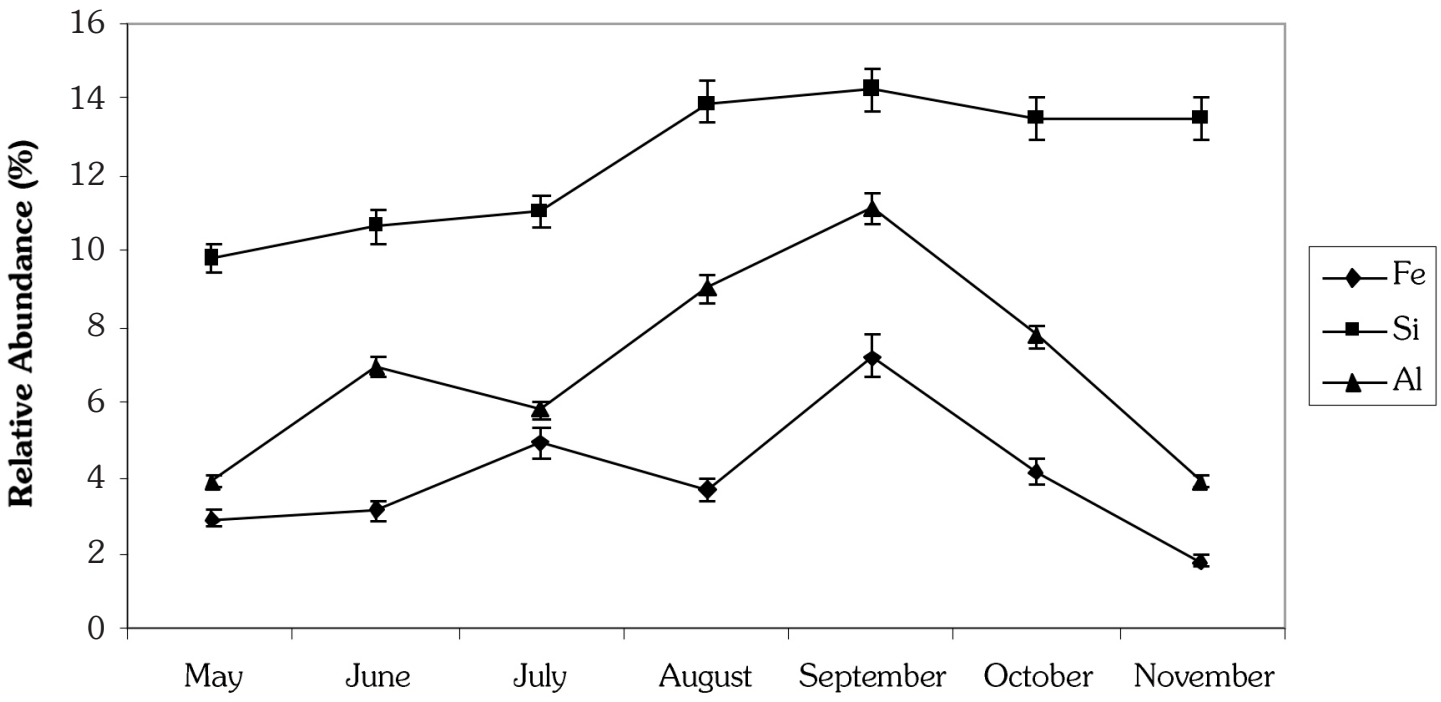

Fig. 2. a) Relative monthly contribution of main elements reaching a maximum during August, expressed as a percentage of the total annual concentration in the snowfall collected during 2008, at the Antarctic sampling station. b) Relative monthly contribution of main elements with a maximum in September, expressed as a percentage of the total annual concentration in the snowfall collected during 2008, at the Antarctic sampling station. In both plots the standard error of the mean value is included. 
simultaneous measurements, by a non-remote sensing technique, have been done in order to get a temporal data for the arrival of material from a specific volcano to Antarctica.

It is a fact that manyelements are incorporated to the ashes as they interact with the plume gases and the atmosphere (Johnston, 1997; Witham et al. 2005), modifying its chemical composition. Therefore, the appearance of sodium is not surprising as the main component in this analysis, it being one of the more abundant elements in the Earth's crust as well as in the atmosphere (Lutgens \& Tarbuck, 2000).

\section{Sulfur}

Because the temporal behavior of sulfur was different to the other elements, the fact of its unusual increase during winter season and consequently remaining at high levels for several months will be discussed separately.

Increased concentrations of sulfur in aerosols are generally reflected by increased concentrations in the snow (Yalcin et al. 2006). Elemental sulfur detected in snow samples may have different origins, such as sea salts, atmospheric oxidation of dimethylsulphide (DMS) emitted by marine phytoplankton (Saltzman et al. 1995; Prospero et al. 1991; Prendez et al. 2009), earth's crust (Cole-Dai et al. 2000), volcanic activity, and anthropogenic sources. As we do not have the capability to distinguish each one of them, for our purposes we are taking them as a whole. The seasonality of mineral dust and sea salt was investigated at Neumayer Antarctic station by Weller et al. (2008) during a four-year study, where they demonstrated a large variation of aerosol composition between winter and summer seasons, showing an increase of sulfur concentration from about $6 \%$ in winter to about $28 \%$ during summer. Jourdain et al. (2001) layered at two coastal Antarctic sites, Neumayer (1983-1995) and Dumont d'Urville (1998-1999); these observations suggest that coastal Antarctic regions are less sensitive than the Antarctic high plateau in receiving volcanic sulfate fallouts following eruptions of global concern. Preunkert et al. (2007), did a multiple year-round study of atmospheric dimethyl sulfide (DMS) (from December 1998 to April 2003) as well as sulfurderived aerosols (methanesulfonic acid (MSA) and non-sea-salt sulfate) from March 1991 to February 2003 at Dumont d'Urville, coastal Antarctica. The three sulfur-derived species exhibit a seasonal cycle characterized by maxima in midsummer (January). All these studies demonstrate that we can expect a natural increase in the abundance of sulfur during summer season.

To assess the impact of the contributions of volcanic material in the sulfur concentration in the aerosol, we considered the amount measured in May as the base line signal. As it is shown in Fig. $2 \mathrm{~A}$, its concentration measured in the snowfall had a significant increase from the month of August and persisted for the next months, reaching up to near $40 \%$ increment when compared to the concentrations shown in May. Since our results present a sharp increase of sulfur concentrations in the middle of winter, we can discard seasonal variations to explain this phenomenon, and relate our observations to an extraordinary source such as the Chaitén volcano.

\section{Isotopic fingerprint}

Isotopic comparison of the contaminants with material from the possible source is one of the tools that geologists are using to identify the origin of material transported to the Antarctic or other territories. As an example, we may mention the work done by Gaiero et al. (2007), who performed a systematic $\mathrm{Sr}$ and $\mathrm{Nd}$ isotopic study of sediment permanently exported to Antarctica. He stated that the chemical and isotopic signatures of Patagonian-sourced sediments are different from those of sediments from the Southern Ocean, the Pampean Region or the Antarctic ice. Therefore, it is possible to identify the source of these sediments without ambiguity.

A relationship between the isotopic ratios of lead was established as a means to find the presence of ashes from the Chaitén among the Antarctic snowfall (Table 2).

For the ratios from the ashes composition ${ }^{206} \mathrm{~Pb} /{ }^{207} \mathrm{~Pb},{ }^{207} \mathrm{~Pb} /{ }^{208} \mathrm{~Pb},{ }^{206} \mathrm{~Pb} /{ }^{208} \mathrm{~Pb}$ we got the following values: $1.20,0.39$ and 0.47 respectively. These values are coincident with the ratios given by the snowfall composition in the month of August. This is another indication that points towards the affirmation that the increments in the concentration 
Table 2. Isotopic ratios of $\mathrm{Pb}$ 206/207, 207/208 y 206/208 in in Chaitén's volcano ashes and Antarctic snowfall from May to November 2008. (All Pb isotope ratio data has been corrected for mass bias and $\mathrm{Tl}$ optimization).

\begin{tabular}{|c|c|c|c|c|c|c|c|c|c|}
\hline \multirow[b]{2}{*}{ Isotope Ratios } & \multirow{2}{*}{$\begin{array}{l}\text { Ash } \\
\text { This } \\
\text { work }\end{array}$} & \multirow{2}{*}{$\begin{array}{c}\text { Ash } \\
\text { Khondoker } \\
2014\end{array}$} & \multicolumn{7}{|c|}{ Isotopic ratios in Antarctic snowfall } \\
\hline & & & May-08 & Jun-08 & Jul-08 & Agu08 & Sep-08 & Oct-08 & Nov-08 \\
\hline${ }^{206} \mathrm{~Pb} /{ }^{207} \mathrm{~Pb}$ & 1.20 & 1.2026 & 0.97 & 1.15 & 1.00 & 1.22 & 1.26 & 1.41 & 1.14 \\
\hline${ }^{207} \mathrm{~Pb} /{ }^{208} \mathrm{~Pb}$ & 0.39 & 0.4036 & 0.46 & 0.38 & 0.40 & 0.39 & 0.41 & 0.34 & 0.44 \\
\hline${ }^{206} \mathrm{~Pb} /{ }^{208} \mathrm{~Pb}$ & 0.47 & 0.4856 & 0.44 & 0.43 & 0.40 & 0.47 & 0.51 & 0.48 & 0.50 \\
\hline
\end{tabular}

of several elements seen during August on the snowfall are due to the contribution of the Chaiten's volcano ashes. These results have been recently confirmed in a work done by Khondoker (2014) in the same ashes samples where the isotopes were determined by an alternative analytical technique (Q-ICP-MS analysis in the 'no gas' mode of the collision-reaction cell (CRC)).

pH

As it is shown in figure 3 , the $\mathrm{pH}$ measured in the snow samples shows an abrupt increase in the month of September. The $\mathrm{pH}$ of the Antarctic snow ranged between 7.04 and 7.52 between May and August. Later, September and October show the highest $\mathrm{pH}$ values measured, with 8.66 and 8.75 respectively, while in November the $\mathrm{pH}$ decreased to 6.86 (Fig. 3). This behavior seems to be consistent with leaching experiments performed on Chaiten's ashes (Ruggieri et al. 2012).

It is difficult to describe chemical phenomena in natural snow systems, since they are very complex, and their chemistry must take many vari- ables into consideration. Therefore, the system must be described by a simplified model, based on some chemical concepts.

In an attempt to explain the basicity of the snow samples, we can consider $\mathrm{Ca}^{2+}, \mathrm{K}^{+}$and $\mathrm{Mg}^{2+}$ (Toom-Sauntry et al. 2002; Kaushar et al. 2010) as some of the known contributors to alkalinity of snow by neutralization of acidic components. Since the two later elements presented a considerable increase in concentration starting in August, as it is shown in Fig. 2A, we may consider that they may be the main factors that explain the increased alkalinity of the snow starting in the month of September.

\section{CONCLUSIONS}

After all the evidences described above, and according to the data collected on the chemical composition of the Chaitén volcano ashes, the chemical composition of the snowfall during the year 2008 and the confirmation given by the lead isotopic ratios within the volcanic ashes composition and the snowfall composition, we can

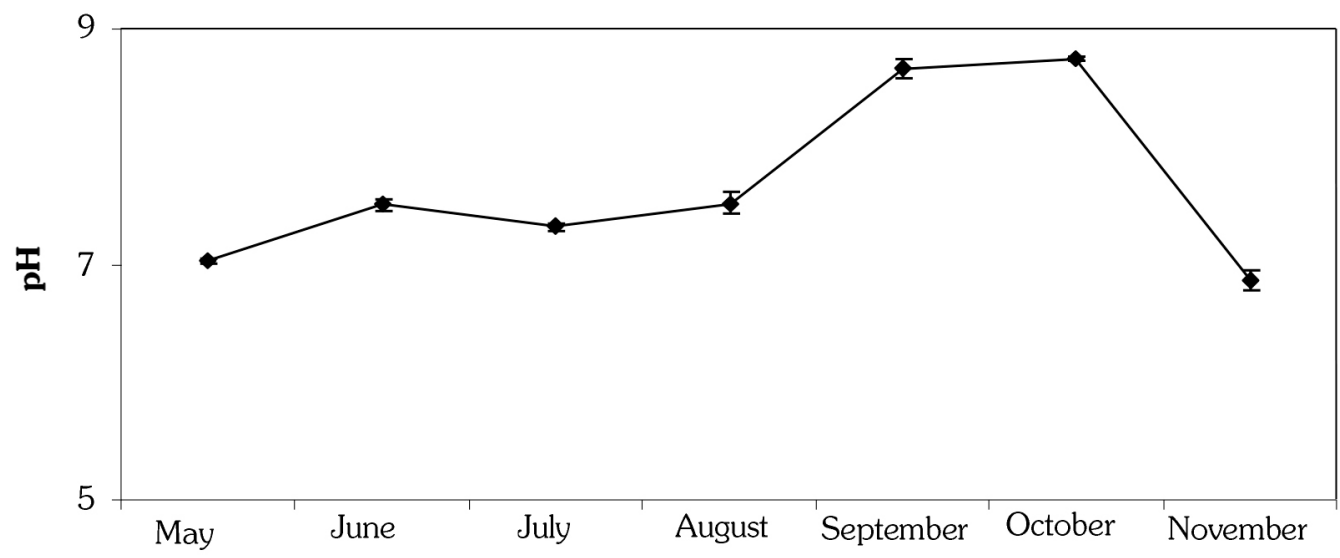

Fig. 3. Measured pH in Antarctic snow collected from May to November 2008.

Standard error of the mean value it is included. 
conclude that the arrival of the Chaitén's volcano eruption materials reached the Antarctic Peninsula in the month of August 2008, four months after the actual event. This source increased the concentration of some elements, such as $\mathrm{Na}, \mathrm{K}, \mathrm{Mg}$ and $\mathrm{Si}$, in the Antarctic snowfall. The $\mathrm{pH}$ of fresh snow precipitation turned basic due to contribution of ashes and a strong increment of sulfur and silicon concentrations was observed in the Antarctic snowfall due to the arrival of the material released by the Chaitén eruption.

\section{ACKNOWLEDGMENTS}

The authors would like to thank the kind support of the University of Magallanes internal Funds, the Antarctic Directorate of the Chilean Army for logistic support, Ms. Irlanda Mora for her assistance in the preparation of maps, as well as Mr. Marcelo Arevalo who participated in the volcanic ash collection.

\section{LITERATURE CITED}

Barrie, L. A., Li, S. M., Toom, D. L., Langsberger, S., \& Sturges, W. (1994). Lower tropospheric measurements of halogens, nitrates and sulphur oxides by denuder and filter systems during Polar Sunrise Experiment. Journal of Geophysical Research, 99 D: 2545325468.

Buduba, C. G., La Manna, L., Alonso, V., \& Irisarri, J. (2008). Carpeta Técnica, Medio Ambiente $N^{\circ} 9$, EEA INTA Esquel.

Bursik, M. I. (2001). Effect of Wind on the Rise Height of Volcanic Plumes. Geophysical Research Letters, 28(18), 3621-3624.

Carn, S. A., Pallister, J. S., Lara, L., Ewert, J. W., Watt, S., Prata, A. J., Thomas, R. J., \& Villarosa, G. (2009). The unexpected awakening of Chaitén volcano, Chile, Eos Trans. AGU, 90(24), 205-206.

Castro, J. M., \& Dingwell, D. B. (2009). Rapid ascent of rhyolitic magma at Chaiten volcano, Chile. Nature, 461(7265), 780783.

Cole-Dai, J., Mosley-Thompson, E., Wight, S. P., \& Thompson, L. G. (2000). A 4100-year record of explosive volcanism from an East
Antarctica ice core. Journal of Geophysical Research, 105(D19), 24431-24441.

Delfosse, T., Elsass, F., \& Delvaux, B. (2005). Direct evidence of basic aluminium sulphate minerals in an S-impacted Andosol. European Journal of Soil Science, 56(3), 281-286.

D'Orazio, M., Innocenti, F., Manetti, P., Tamponi, M., Tonarini, S., Gonzalez-Ferran, O., Lahsen, A., \& Omarini, R. (2003) Journal of South American Earth Sciences, 16(4), 219-242.

Dorries, M. (2006). In the public eye: Volcanology and climate change studies in the 20th century. Historical Studies in the Physical and Biological Sciences, 37, 87-125.

Fischer, E. M., Luterbacher, J., Zorita, E., Tett, S. F. B., Casty, C., \& Wanner, H. (2007). European climate response to tropical volcanic eruptions over the last half millennium. Geophysical Research Letters, 34(5), L05707.

Gaiero, D. M., Brunet, F., Probst, J. L., \& Depetris, P. J. (2007). A uniform isotopic and chemical signature of dust exported from Patagonia: Rock sources and occurrence in southern environments. Chemical Geology, 238, 107-120.

Gao, C. H., Oman, L., Robock, A., \& Stenchikov, G. L. (2007). Atmospheric volcanic loading derived from bipolar ice cores: Accounting for the spatial distribution of volcanic deposition. Journal of Geophysical research-Atmospheres, 112(D9), D09109.

Gauci, V., Dise, N.B., Howell, G., \& Jenkins, M. E. (2008). Suppression of rice methane emission by sulfate deposition in simulated acid rain. Journal of Geophysical ResearchBiogeosciences, 113, G00A07.

Global Vulcanism Program, (2008). Smithsonian Institution, www.volcano.si.edu, acceced on July 29.

Grigholm, B., Mayewski, P. A., Kurbatov, A. V., Casassa, G., Staeding, A. Contreras, Handley, M., Sneed, S. B., \& Introne D. S. (2009). Chemical composition of fresh snow from Glaciar Marinelli, Tierra del Fuego, Chile. Journal of Glaciology, 55(8), 769776. 
Gutierrez, F., Gioncada, A., Ferran, O. G., Lahsen, A., \& Mazzuoli, R. (2005). The Hudson Volcano and surrounding monogenetic centres (Chilean Patagonia): An example of volcanism associated with ridgetrench collision environment. Journal of Volcanology and Geothermal Research, 145(3-4), 207-233.

Hickey- Vargas, R., Abdollahi, M. J., Parada, M. A., Lopez-Escobar, L., \& Frey, F. A. (1995). Crustal Xenoliths from Calbuco Volcano, Andean Southern Volcanic Zone-Implications for Crustal Composition and Magma-Crust Interaction. Contributions to Mineralogy and Petrology, 119(4), 331-344.

Johnston, D. M. (1997). Physical and social impacts of past and future volcanic eruptions in New Zealand, Ph.D. thesis, University of Canterbury, Christchurch, pp. 288.

Jones, M. T., \& Gislason, S. R. (2008). Rapid releases of metal salts and nutrients following the deposition of volcanic ash into aqueous environments. Geochimica et Cosmochimica Acta, 72(15), 3661-3680.

Jourdain, B., \& Legrand, M. (2001). Seasonal variations of atmospheric dimethylsulfide, dimethylsulfoxide, sulfur dioxide, methanesulfonate, and non-sea-salt sulfate aerosols at Dumont d'Urville (coastal Antarctica) (December 1998 to July 1999), Journal of Geophysical ResearchAtmospheres, 106, D13, 14391-14408.

Kaushar, A., Sonbawane, S., Chate, D. M., Siingh, D., Rao, P. S. P., Safai, P. D., \& Budhavant, K. B. (2010). Chemistry of snow and lake water in Antarctic region. Journal of Earth System Science, 119(6), 753-762.

Khondoker, R. (2014) Human impact on dust entering the South Atlantic Ocean and the consequential impact on marine biogeochemical cycles. Ph.D. thesis, Imperial College London, London.

Laluraj, C. M., Krishnan, K. P., Thamban, M., Mohan, R., Naik, S. S., D'Souza, W., Ravindra, R., \& Chaturvedi, A. (2009). Origin and characterisation of microparticles in an ice core from the Central Dronning Maud Land, East Antarctica. Environmental Monitoring Assessment, 149, 377-383.
Lopez-Escobar, L., Kilian, R., Kempton, P. D., \& Tagiri, M. (1993). Petrography and Geochemistry of Quaternary Rocks from the Southern Volcanic Zone of the Andes Between 41-degrees-30'S and 46-degrees-00'S, Chile. Revista Geologica de Chile, 20(1), 33-55.

Lopez-Escobar, L., Parada, M. A., HickeyVargas, R., Frey, F. A., Kempton, P. D., \& Moreno, H. (1995). Calbuco Volcano and Minor Eruptive Centers Distributed Along The Liquiñe-Ofqui Fault Zone, Chile (41-degrees-S 42-degrees-S), Contrasting Origin of Andesitic and Basaltic Magma in the Southern Volcanic Zone of the Andes. Contributions to Mineralogy and Petrology, 119(4), 345-361.

Lutgens, F. K. \& Tarbuck, E. J. (2000). Essentials of Geology.7th Ed., Prentice Hall.

Major J. J. \& Lara L. E. (2013) Overview of Chaitén Volcano, Chile, and its 2008-2009 eruption. Andean Geology, 40(2), 196215.

Martin, R. S., Watt, S. F. L., Pyle, D. M., Mather, T. A., Matthews, N. E., Georg, R. B., Day, J. A.,...\& Quayle, B. M. (2009). Environmental effects of ashfall in Argentina from the 2008 Chaitén volcanic eruption. Journal of Volcanology and Geothermal Research, 184(3-4), 462-472.

Millard, G. A., Mather, T. A., Pyle, D. M., Rose, W. I., \& Thornton, B. F. (2006). Geophysical Research Letters, 33, L19815.

Naranjo J. A., \& Stern, C. R. (2004). Holocene tephrochronology of the southernmost part (42 degrees 30'-45 degrees S) of the Andean Southern Volcanic Zone. Revista Geológica de Chile, 31(2), 225-240.

Ottera, O. H. (2008). Simulating the effects of the 1991 Mount Pinatubo volcanic eruption using the ARPEGE atmosphere general circulation model. Advances in Atmospheric Sciences, 25(2), 213-226.

Prata, F., Carn, S. A., Fromm, M., \& Krotkov, N. A. (2008). A-Train satellite observations of the Chaitén eruption clouds. Proceedings, American Geophysical Union, Fall Meeting, San Francisco, California, 15-19 December.

Prendez M., Wachter, J., Vega, C., Flocchini, R.G., 
Wakayabashi, P., \& Morales, J. R. (2009). PM2.5 aerosols collected in the Antarctic Peninsula with a solar powered sampler during austral summer periods. Atmospheric Environment, 43, 5575-5578.

Preunkert, S., Legrand, M., Jourdain, B., Moulin, C., Belviso, S., Kasamatsu, N., Fukuchi, M., \& Hirawake, T. (2007). Interannual variability of dimethylsulfide in air and seawater and its atmospheric oxidation byproducts (methanesulfonate and sulfate) at Dumont d'Urville, coastal Antarctica (19992003). Journal of Geophysical researchAtmospheres, 112, D6, D06306.

Prospero, J. M., Savoie, D. L., Saltzman, E. S., \& Larsen, R. (1991). Impact of oceanic sources of biogenic sulphur on sulphate aerosol concentrations at Mawson, Antarctica. Nature, 350, 221-223.

Prospero, J. M., Ginoux, P., Torres, O., Nicholson, S. E., \& Gill, T. E. (2002). Environmental characterization of global sources of atmospheric soil dust identified with the Nimbus 7 Total Ozone Mapping Spectrometer (TOMS) absorbing aerosol product. Rev. Geophys, 40(1), 1002.

Robock, A. (2000). Volcanic eruptions and climate. Reviews of Geophysics, 38(2), 191-219.

Ruggieri, F., Fernandez-Turiel, J. L., Saavedra, J., Gimeno, D., Polanco, E., \& Naranjo, J. A. (2011). Environmental geochemistry of recent volcanic ashes from the Southern Andes. Environmental Chemistry, 8, 236247.

Ruggieri, F., Fernandez-Turiel, J. L., Saavedra, J., Gimeno, D., Polanco, E., Amigo. A., Galindo. G., \& Caselli, A. (2012). Contribution of volcanic ashes to the regional geochemical balance: The 2008 eruption of Chaitén volcano, Southern Chile. Science of the Total Environment, 425, 75-88.

Saltzman, E. S. (1995). Ocean/atmosphere cycling of dimethylsulfide. In R. J. Delmas (Ed.) Ice-core studies of global biogeochemical cycle. NATO ASI Series. Series I, global environmental change (vol. 30, pp. 65-89). Berlin: Springer.

Sato, M., Hansen, J. E., McCornick, M. P., \& Pollack, J. B. (1993). Stratospheric Aerosol Optical
Depths 1850-1990. Journal Geophysical. Research, 98(D12), 22987-22994.

Selles, D., Rodriguez, A. C., Dungan, M. A., Naranjo, J. A., \& Gardeweg, M. (2004). Geochemistry of Nevado de Longavi Volcano (36.2 degrees S): a compositionally atypical arc volcano in the Southern Volcanic Zone of the Andes. Revista Geológica De Chile, 31(2), 293-315.

Tilmes S., Muller, R., \& Salawitch, R. (2008). The sensitivity of polar ozone depletion to proposed geoengineering schemes. Science, 320(5880), 1201-1204.

Toom-Sauntry D., L. A. Barrie (2002). Chemical composition of snowfall in the high Arctic: 1990-1994 Atmospheric Environment, 36, 2683-2693.

Von Glasow, R., Bobrowski, N., \& Kern, C. (2008). The effects of volcanic eruptions on atmospheric chemistry. Chemical Geology. 263(1-4), 131-142.

Weiss, D. J., Kober, B., Dolgopolova, A., Gallagher, K., Spiro, B., Le Roux, G., \& Coles, B. J. (2004).Accurate and precise $\mathrm{Pb}$ isotope ratio measurements in environmental samples by MC-ICP-MS. International Journal of Mass Spectrometry, 232(3), 205-215.

Weller, R., Oltjen J. W., Piel C., Resenberg R., Wagenbach D., Nig-Langlo G. K. \& Kriews, M. (2008). Seasonal variability of crustal and marine trace elements in the aerosol at Neumayer Station, Antarctica. Tellus, 60B, 742-752.

Witham, C. S., Oppenheimer, C., \& Horwell, C. J. (2005). Journal of volcanology and Geothermal Research, 141, 229-326.

Yalcin, K., Wake, C. P., Dibb, J. E., Whitlow, S. I. (2006). Atmospheric Environment, 40, 7152-7163.

Zielinski, G. A. (2000). Use of paleo-records in determining variability within the volcanismclimate system. Quaternary Science, Review, 19, 417-438.

Zielinski, G. A., Dibb, J. E., Yang, Q., Mayewski, P. A., Whitlow, S., \& Twickler, M. S.(1997). Assessment of the record of the $1982 \mathrm{El}$ Chichón eruption as preserved in Greenland snow. Journal of Geophysics Research, 102, 30031-30045. 
